\title{
NUMERICAL SIMULATION AND ANALYSIS OF COANDA EFFECT CIRCULATION CONTROL FOR WIND-TURBINE APPLICATION CONSIDERATIONS
}

\author{
H.DJOJODIHARDJO ${ }^{1}$, M.F.ABDULHAMID ${ }^{2}$, S. BASRI ${ }^{2}$, F. I. ROMLI ${ }^{2}$ \\ AND D. L. A. ABDUl MAJID ${ }^{2}$ \\ ${ }^{1}$ Universitas Al-Azhar Indonesia, Jakarta, Indonesia \\ ${ }^{2}$ Department of Aerospace Engineering, Faculty of Engineering, \\ University Putra Malaysia (UPM), \\ 43400 UPM Serdang, Selangor Darul Ehsan, Malaysia. \\ harijono@djojodihardjo.com
}

\begin{abstract}
In the efforts to investigate the performance of Coanda Jet in enhancing lift of an airfoil, a numerical study is carried out. Tangential jets that take advantage of Coanda effect to closely follow the contours of the body are considered to be simple and particularly effective in that they can entrain a large mass of surrounding air. This can lead to increased circulation in the case of airfoils, or drag reduction (or drag increase if desired) in the case of bluff bodies such as an aircraft fuselage. Critical review and analysis is also carried out for the application of Coanda Jet to optimize the aerodynamic performance of wind turbine, using the results of the numerical study and taking advantage of recent efforts to introduce Coanda effect as a novel circulation control technique. For this purpose a simple twodimensional CFD modeling is utilized to reveal the key elements that could exhibit the desired performance criteria, in particular the lift enhancement and drag reduction, or a combination of both. Three dimensional configurations will be synthesized using certain acceptable assumptions, to compare such results with existing experimental data. Hence in this work the problem is idealized as basic airflow over a two-dimensional airfoil in subsonic flow; by the use of CFD technique, parametric study is carried out to arrive at plausible design considerations and to assess the practicability of Coanda jet in wind turbine design. Parametric study carried out shows the effectiveness of Coanda-jet in producing enhanced lift, which can contribute to increased torque in wind turbine application and increased axial thrust for propeller application. The numerical study also shows that appropriate trailing edge rounding off and tailoring the Coanda-jet thickness and momentum coefficient can produce enhanced lift to drag ratio.
\end{abstract}

ABSTRAK:Dalam usaha untuk mengkaji prestasi Coanda Jet bagi mempertingkatkan daya angkat suatu aerofil, kajian berangka telah dijalankan. Tangen jet yang mengambil manfaat efek Coanda mengikut kontur permukaan dianggap mudah dan berkesankerana ia dapat mengiring satu jisim besar udara sekeliling. Ini mendorong kepada penambahan edaran udara dalam kes aerofil, atau penurunan seret (juga penambahan seret jika diingini) dalam kes jasad tubir seperti fiuslaj pesawat.Ulasan kritikal dan analisis telah dijalankan bagi aplikasi Coanda Jet untuk mengoptimumkan prestasi aerodinamik turbin angin, menggunakan keputusan kajian berangka dan mengambil manfaat usahamemperkenalkan penggunaan efek Coanda sebagai satu teknik pengawalan edaran udara. Untuk tujuan ini, permodelan dua dimensi CFD telah digunakan untuk mendedahkan punca utama elemen yang dapat mededahkan kriteria prestasi yang diingini, khususnya peningkatan daya angkat 
dan penurunan seret, ataupun kombinasi kedua-duanya.Konfigurasi tiga dimensi akan disintesis menggunakan beberapa andaian yang boleh diterima, untuk membandingkan keputusan tersebut dengan data eksperimental yang sedia ada.Permasalahan dalam kajian ini diunggulkan sebagai aliran udara asas subsonik di atas aerofil dua dimensi; dengan menggunakan teknik CFD, kajian berparameter dijalankan untuk mendapat reka bentuk yang munasabah, dan mengkaji kebolehlaksanaan Coanda jet dalam reka bentuk turbin angin.Kajian berparameter menunjukkan keberkesanan Coanda-jet dalam menghasilkan peningkatan daya angkat, justeru menyumbangkan kepada peningkatan daya kilas dalam aplikasi turbin angin, dan juga penambahan tujah paksi dalam aplikasi bebaling.Kajian berangka ini juga menunjukkan pembundaran pinggir mengekor, pemilihan ketebalan Coanda-jet dan pekali momentum yang sesuai, akanmenghasilkan peningkatan nisbah daya angkat terhadap seretan.

KEYWORDS: aerodynamics, wind-energy, computational fluid dynamics, numerical method

\section{INTRODUCTION}

The interest in the use of flow control for enhanced aerodynamic performance has grown, in particular the use of jets (continuous, synthetic, pulsed, etc.) [1-14]. It is widely documented that these active control concepts can dramatically alter the behavior of aerodynamic components such as airfoils, wings, and bodies.

In this conjunction, and with the progress of CFD, the use of Coanda effect to enhance lift has attracted renewed interest [2-5, 8-12, 17-19]. Tangential jets that take advantage of Coanda effect to closely follow the contours of the body are considered to be simple and particularly effective in that they can entrain a large mass of surrounding air. This can lead to increased circulation in the case of airfoils, or drag reduction (or drag increase if desired) in the case of bluff bodies such as an aircraft fuselage. Figure 1 (a) illustrates the utilization of Coanda jet for enhancing lift in a proposed aircraft [2,15], while Fig. 1 (b) illustrates the concept of Coanda-effect jet tangential blowing over trailing edge surface for Lift Enhancement [3].

In the design of a novel wind-turbines, in particular for large windturbines in land-based or off-shore wind-farms for significant renewable energy contribution, in which the Reynolds number may reach $5 \times 10^{6}$ or above [20, 21], using the latest aerospace engineering technology, including aerodynamics, new light-weight materials, and efficient energy extraction technology, highly efficient aerodynamic surface came as a key issue. Recent efforts in the last decade have also indicated that Coanda effect has been given new and considerable considerations for circulation control technique [16-19]. Taking advantage of these recent results, the present work will look into the effort to optimize aerodynamic performance of wind turbines and to critically review the use of Coanda effect.

The progress of high speed computers exemplified by the availability of new generations of notebooks has made possible the use of first-principles-based computational approaches for the aerodynamic modeling of wind turbine blades, to name an example. As pointed out by Sankar [8, 16-17], since these approaches are based on the laws of conservation of mass, momentum, and energy, they can capture much of the physics in great detail. These approaches are particularly helpful at high wind speeds, where appreciable regions of separation are present and the flow is unsteady. 
In the design of circulation control technique, one may note the progress of stallcontrolled and pitch controlled turbine rotor technology for dealing with power production at low and high wind conditions, as pointed out by Tangler et al. [20]. Of interest is the deployment of wind turbines at larger range of sites not limited to a relatively small number of sites where favorable conditions exist. At the other extreme, precautions should be taken when the wind speeds become very high, when the rotor invariably stalls and experiences highly unsteady aerodynamic forces and moments. It is noted that over the past several years, there has been an increased effort to extend the usable operating range of stall regulated wind turbines. The concepts of circulation control through trailing edge blowing, or Coanda-jets, then came into view.

For this purpose, in this particular work we will focus on a particular problem, i.e. the basic airflow idealization over a two-dimensional airfoil in subsonic flow. Two specific airfoils will be considered. The first is an airfoil that has already been investigated thoroughly, for benchmarking. For this purpose the NACA 2412 airfoil has been chosen.

Tangler et al. [20] argue that over the past decades, commonly used airfoil families for horizontal axis wind turbines suffer noticeable performance degradation from roughness effects resulting from leading-edge contamination. Considerations are also taken on the notion that annual energy losses due to leading-edge roughness are greatest for stall-regulated rotors. The loss is largely proportional to the reduction in maximum lift coefficient $\left(\mathrm{C}_{\mathrm{L}_{\max }}\right)$ along the blade. High blade-root twist helps reduce the loss by keeping the blade's angle-of attack distribution away from stall which delays the onset of $C_{L_{\text {max }}}$. New series of blades suitable for wind-turbine applications have been developed at NREL [20]. Because of the economic benefits provided by these airfoils, they are recommended for retrofit blades and most new wind turbine designs [20]. In order to obtain results that can be well assessed, especially with reference to extensive research carried out as described in [16-19], S809 airfoil [20] is considered in the present work.

\section{PROBLEM FORMULATION}

Circulation control wing (CCW) technology is known to be beneficial in increasing the bound circulation and hence the sectional lift coefficient of airfoil. This technology has been extensively investigated both experimentally and numerically [1-19] over many years. Circulation control is implemented by tangentially blowing a small high-velocity jet over a highly curved surface, such as a rounded trailing edge. This causes the boundary layer and the jet sheet to remain attached along the curved surface due to the Coanda effect (a balance of the pressure and centrifugal forces) and causing the jet to turn without separation. The rear stagnation point location moves toward the lower airfoil surface, producing additional increase in circulation around the entire airfoil. The outer irrotational flow is also turned substantially, leading to high value of lift coefficient comparable to that achievable from conventional high lift systems, as indicated in Fig. 1(b).

Tongchitpakdee [17-18] observed that early Circulation Controlled Wing designs typically had a large-radius rounded trailing edge to maximize the lift benefit. These 

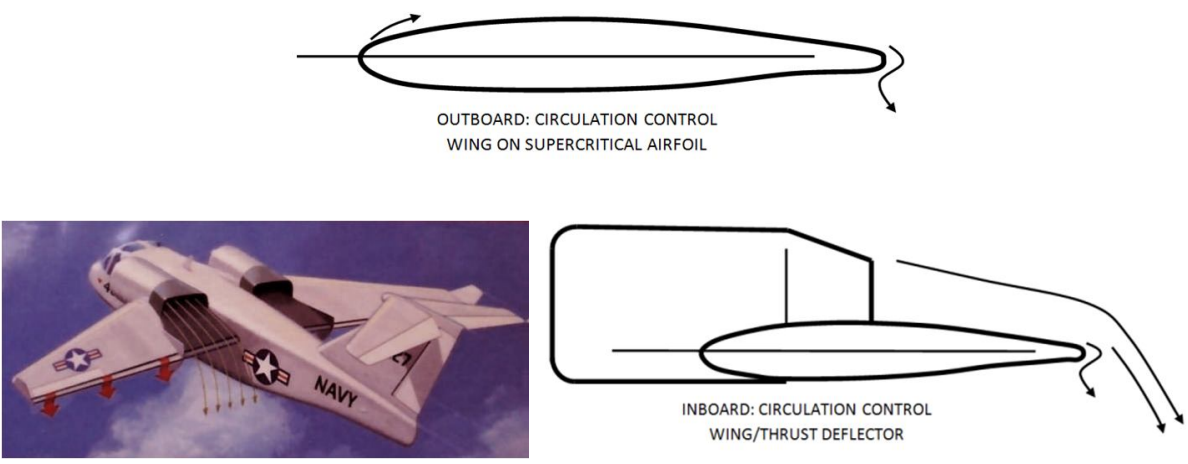

(a)

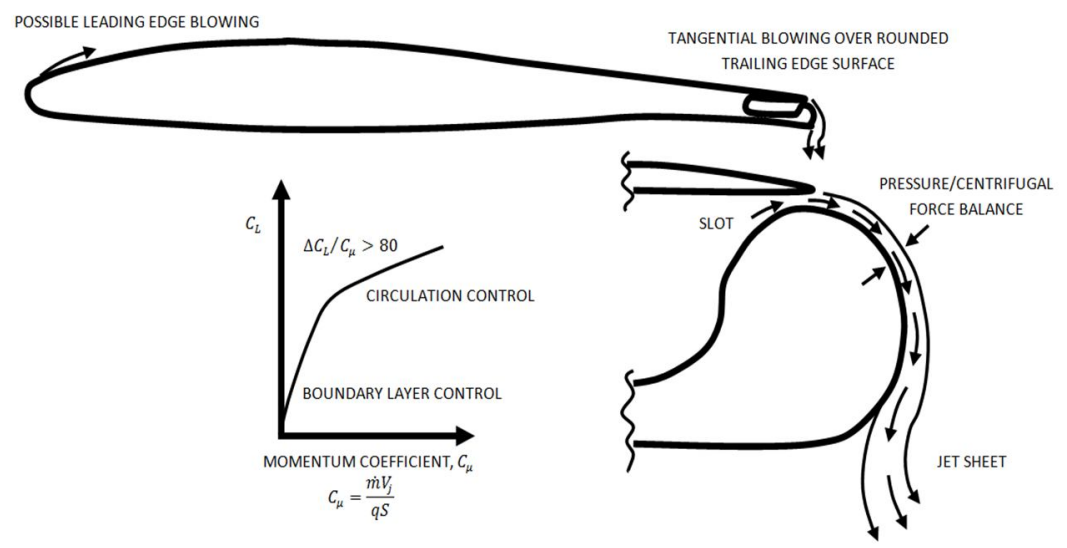

(b)

Fig. 1: Illustration of Coanda-jet like circulation control: (a) Circulation Control Wing-Upper Surface Blowing STOL aircraft configuration, from [2, 15]; (b) Coanda-effect jet tangential blowing over trailing edge surface for lift enhancement, from [3].

designs, however, also result in high drag penalty when the jet is turned off. One way to reduce this drag is to make the lower surface of the trailing edge a flat surface, while keeping the upper surface highly curved. This curvature on the upper surface produces a large jet turning angle, leading to high lift. In this conjunction, the ability of circulation control technology to produce large values of lift advantageous for wind turbine design since any increase in the magnitude of the lift force (while keeping drag small, and L/D high) will immediately contribute to a corresponding increase in induced thrust and torque will be taken into consideration.

Numerical simulation carried out by previous investigator (Tongchitpakdee $[17,18]$ ) looked into two approaches of introducing Coanda jet, i.e., at the appropriately chosen point in the vicinity of the trailing as well as leading edge. A leading edge blowing jet was found to be helpful in increasing power generation at leading edge separation cases, while atrailing edge blowing jet otherwise. With such background the present work is aimed at the search for favorable Coanda-jet lift enhanced configuration for windmill designs. 
For this purpose, a rigorous review of Coanda-jet circulation control airfoil in twodimensional subsonic flow is performed. Numerical simulation using commercially available Navier-Stokes CFD codes is carried out and critically analyzed. Results obtained from recent researches will be utilized for validation. Tongchitpakdee [18] found that best lift enhancing effect could be facilitated by designing the lower part of the trailing edge surface to be flat and this finding is also incorporated in the present numerical investigation.

The case studies performed here use normalized dimension: airfoil chord length of $1 \mathrm{~m}$. These correspond to a Reynolds number of the order of $10^{6}$, which is considered to be a typical situation.

\section{OBJECTIVES}

In the combined theoretical and numerical analyses, one is lead to come up with desired logical cause and effect laws as well as to find ways to carry out optimization schemes to arrive at desired design configurations. It is with such objectives in mind that parametric studies may offer some clues on relevant parameters which may be utilized in a multi-variable optimization (and to a larger scale, multi-disciplinary optimization). In this conjunction, the present work will address the following aspects:

a) The influence and the effectiveness of the Coanda enhanced lift for a comprehensive series of configurations, for axial thrust (lift), mass flow rate or torque producing mode; the corresponding gain or changes in lift, drag (or L/D ratio) will be assessed.

b) Parametric study for obtaining optimum configuration of the Coanda effect lift enhanced airfoil.

c) The feasibility and practicability of Coanda configured airfoil for wind-turbine applications.

\section{METHODOLOGY, COMPUTATIONAL SET-UP AND VALIDATION}

\subsection{Bases of Numerical Analysis}

In this approach, two-dimensional unsteady compressible Reynolds-averaged NavierStokes equations are solved in integral form on a computational grid surrounding a reference airfoil using the finite volume method. The CFD code utilized for this purpose is COMSOL® ${ }^{1}$.

Prior to its utilization, various baseline cases have been tried out, with favorable results. As a case in point, for benchmarking purposes the code has been applied to calculate the liftslope characteristics of NACA2412 airfoil. The results as shown in Fig. 2 demonstrated its applicability for the present investigation.

All computations in the present study were performed on a laptop computer with a 2.00 $\mathrm{GHz}$ Intel Core Duo processor, $1 \mathrm{~GB}$ of RAM, and 32-bit Operating System. Typical computation time for the computation of the flow characteristics around a two dimensional airfoil is 115.565 seconds with 62243 degrees of freedom by using stationary segregated

\footnotetext{
${ }^{1}$ made available for our present work for trial purposes by I-Math Co., Singapore.
} 
solver in $k-\omega$ turbulent model analysis. With such computational environment, which in consequence limits the computational grids, the present work will seek and adopt appropriate CFD numerical procedures. Simplified theoretical analysis is carried out prior to the modeling and numerical computation, while further theoretical analysis will be carried out in evaluating the computational results.

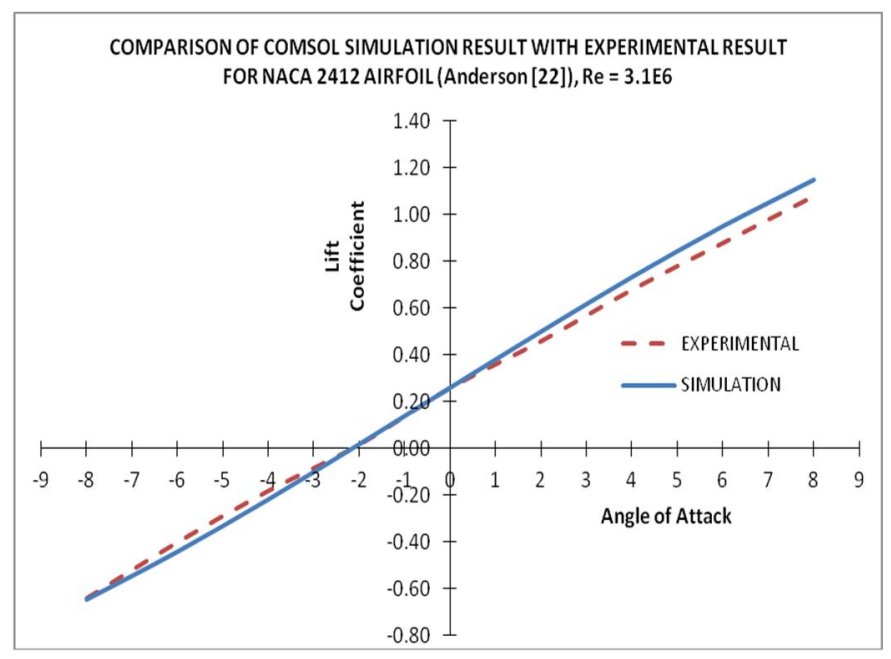

Fig. 2: Comparison of Lift-curve slope of NACA2412 airfoil from CFD computation using COMSOL code and experimental values $[22,28]$.

An objective review and analysis of the application of the first principle in the numerical computation will be carried out prior to the utilization of commercially available CFD codes for the present study. For this purpose some baseline validation is made.

The comprehensive results as addressed in the objective of the work will be assessed to establish key findings that will contribute to the physical basis of Coanda jets for lift enhancement in aerodynamic lifting surfaces. An analysis based on physical considerations will be carried out with reference to their application in propeller (or helicopter rotor) and wind-turbine blade configuration for design purposes.

\subsection{Computational Grid}

In the present work, all calculations were performed by free mesh parameter grid generation using an algebraic grid generator. The meshing was carried out using free mesh parameter grid generator and varies from extremely coarse grid up to extremely fine grid. However, for the S809 airfoil case, near the surface of the airfoil, boundary-layer based meshing is carried out throughout. Grid sensitivity study on the lift force per unit span for clean airfoil at zero angle of attack were plotted as depicted in Fig. 3 and Table 1 which defines and indicates the range of free mesh parameter.

Figure 3 shows that the slope of the line starting from normal meshing grid size becomes stable after fine grid is generated. Therefore, the present analysis can be assumed to have an acceptable grid size with the choice of grid size in the range of normal up to extremely fine grid size since within this range the lift force does not change appreciably. 


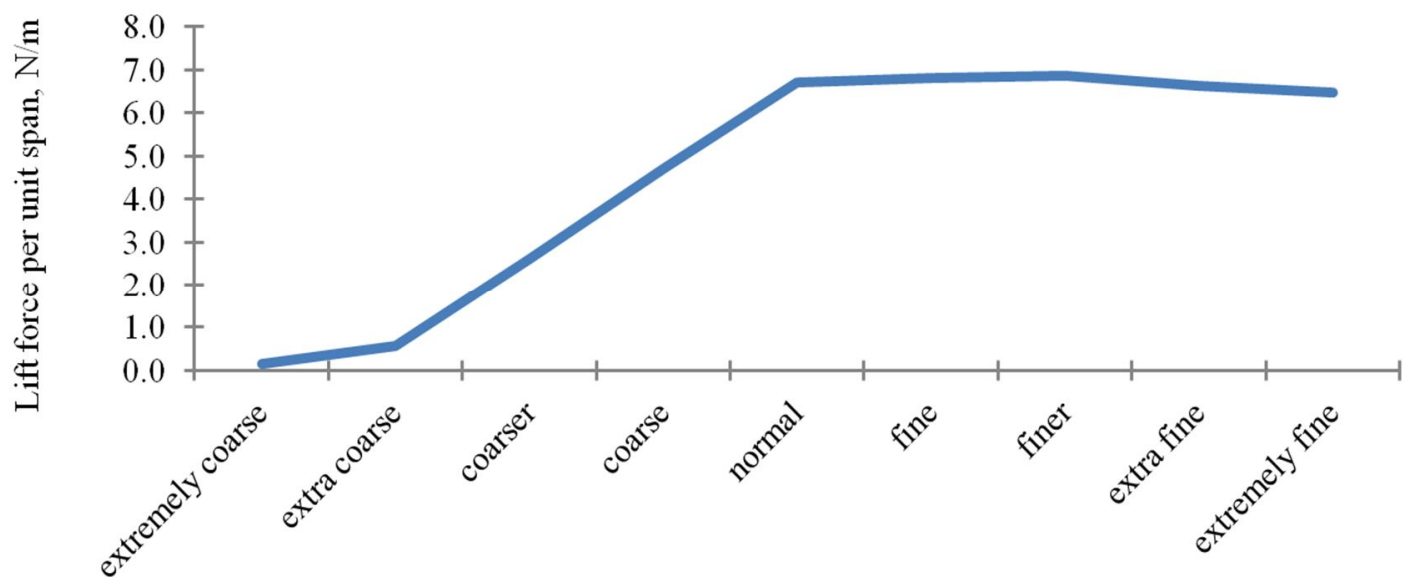

Fig. 3: Grid sensitivity study on lift force per unit span for clean airfoil at zero degree angle of attack.

Table 1: The range of free mesh parameters.

\begin{tabular}{|l|c|}
\hline \multicolumn{1}{|c|}{ Parameter } & Range \\
\hline Maximum element size scaling factor & $0.15-1$ \\
\hline Element growth rate & $1.2-1.3$ \\
\hline Mesh curvature factor & $0.2-0.3$ \\
\hline Mesh curvature cut-off & $0.0001-0.001$ \\
\hline
\end{tabular}

The grid generator is sufficiently general so that one can easily vary the jet slot location and size. Grid spacing and clustering can have significant effects on wind turbine load and performance predictions, as reported in Benjanirat [27]. In this conjunction, grid spacing and clustering have been considered carefully here, adjusted and verified following considerations depicted by Fig. 3 and Table 1. The computational domain and the grid in the vicinity of the airfoil surface and Coanda-jet slot are exhibited in Fig. 4.

\subsection{TurbulenceModeling Considerations}

Based on results established in the literature, the Menter's Shear Stress Transport (SST) $\mathrm{k}-\omega$ turbulent model [23] will be adopted as the baseline in the present investigation. The application of such model and its acceptability in view of the objectives set up above should be assessed, in particular with the application of Menter's SST k- $\omega$ or the Spalart-Almaras (SA) turbulent model. The turbulent model is used to define the wall function $y+$, which is widely employed to model the near-wall region. The idea is to place the first computational node outside the viscous sub layer, and make suitable assumptions about how the near-wall velocity profile behaves, in order to obtain the wall shear stress. Wall functions use empirical laws to circumvent the inability of the $\mathrm{k}-\omega$ model to predict a logarithmic velocity profile near a wall. With these laws it is possible to express the mean velocity parallel to the wall and turbulence quantities outside the viscous sub layer in terms of the distance to the wall and wall conditions such as wall shear stress and pressure gradient, among others. Hence, the wall 
functions can be used to provide near-wall boundary conditions for the momentum and turbulence transport equations, rather than conditions at the wall itself, so that the viscous sub layer does not have to be resolved and the need for a very fine mesh is circumvented.The $y+$ values obtained using a chosen turbulent model are used as reference in the selection of gridsize near the airfoil surface and assessing the validity of the present computational results using COMSOL $®$, since the Coanda-jet thickness studied may be in the order of the local boundary layer thickness. Figure 5 illustrates the state of affairs.

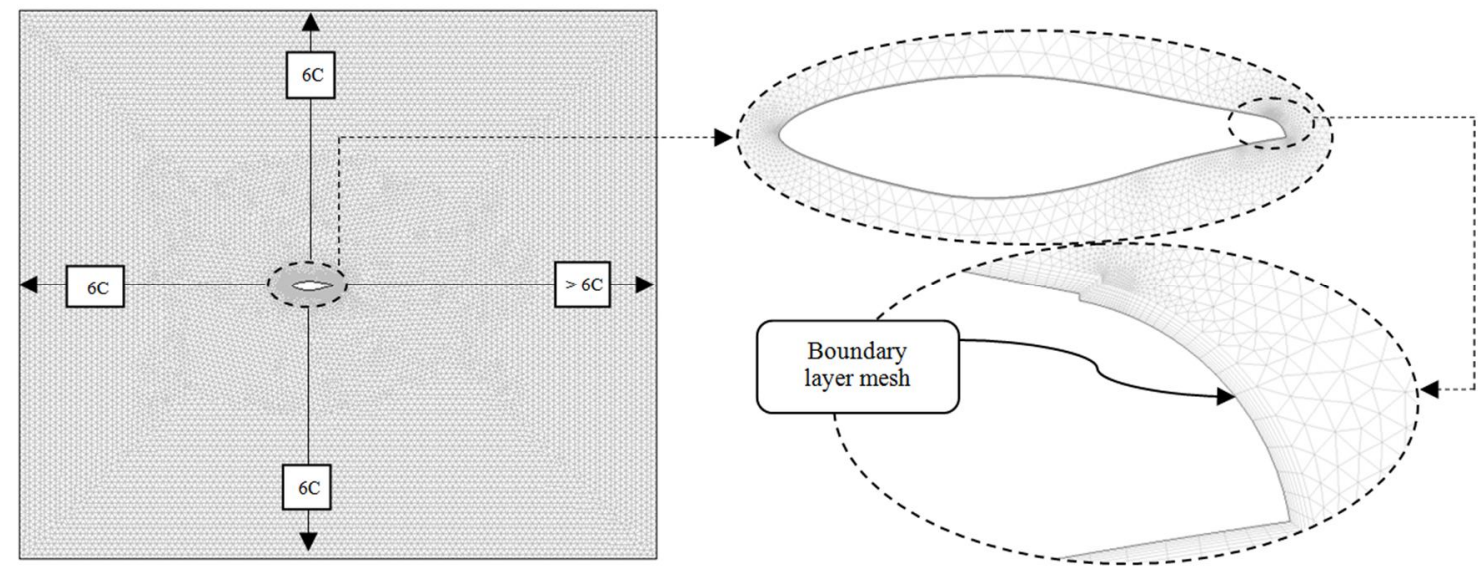

(a)

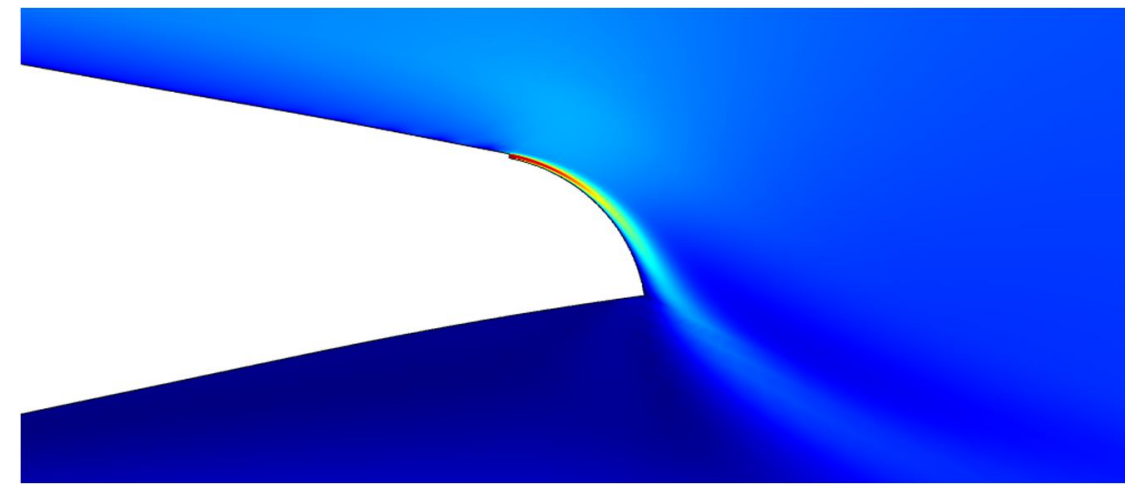

(b)

Fig. 4: (a) Computational Grid around a Typical Airfoil, shown here for S809 Airfoil; (b) Detail of a typical flow field in the vicinity of the Coanda-jet near the trailing edge.

In the utilization of the COMSOL® CFD code for the numerical experiments, careful considerations have been given in the appropriateness of the turbulence model adopted, in order to justify the numerical results obtained in the Coanda-jet configured airfoil in the vicinity of the trailing edge. For this purpose the following review and analysis provide relevant information as a basis for the plausibility of the computational procedure adopted. The dimensionless, sub-layer scaled, distance in the boundary layer, signifying viscoussublayer length scale plays significant role in assessing the turbulence model utilized and the computation of flow characteristics associated with turbulent flow. Similar to local Reynolds number, the wall $\mathrm{y}+$ is often used in CFD to describe how coarse or fine a mesh is for a particular flow. It is the ratio between the turbulent and laminar influences in a cell. 


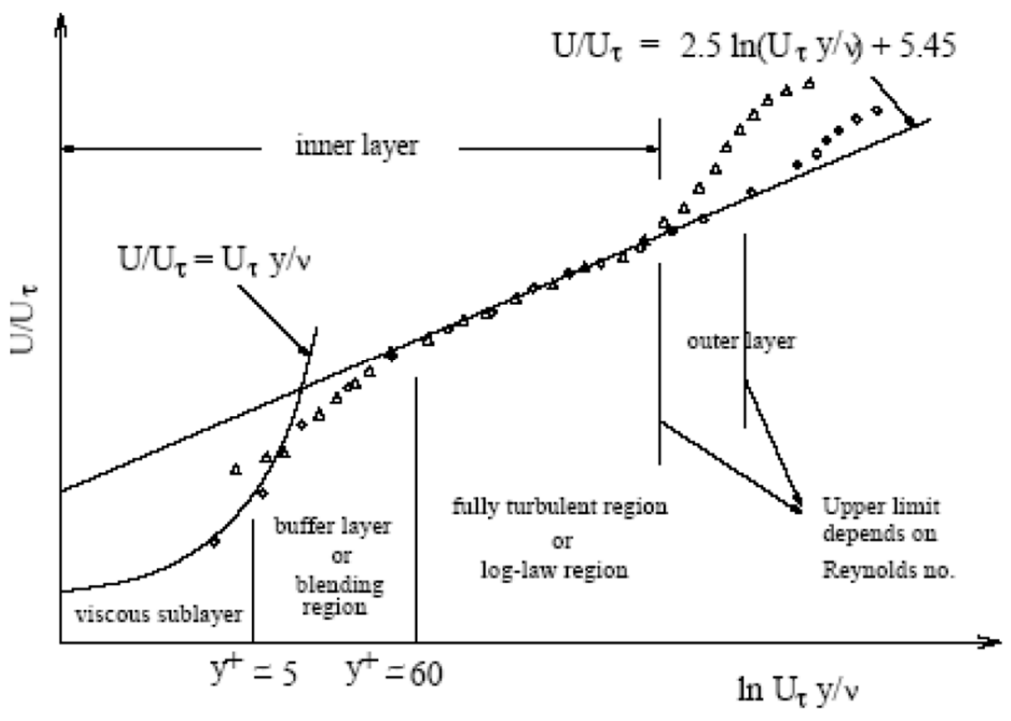

(a)
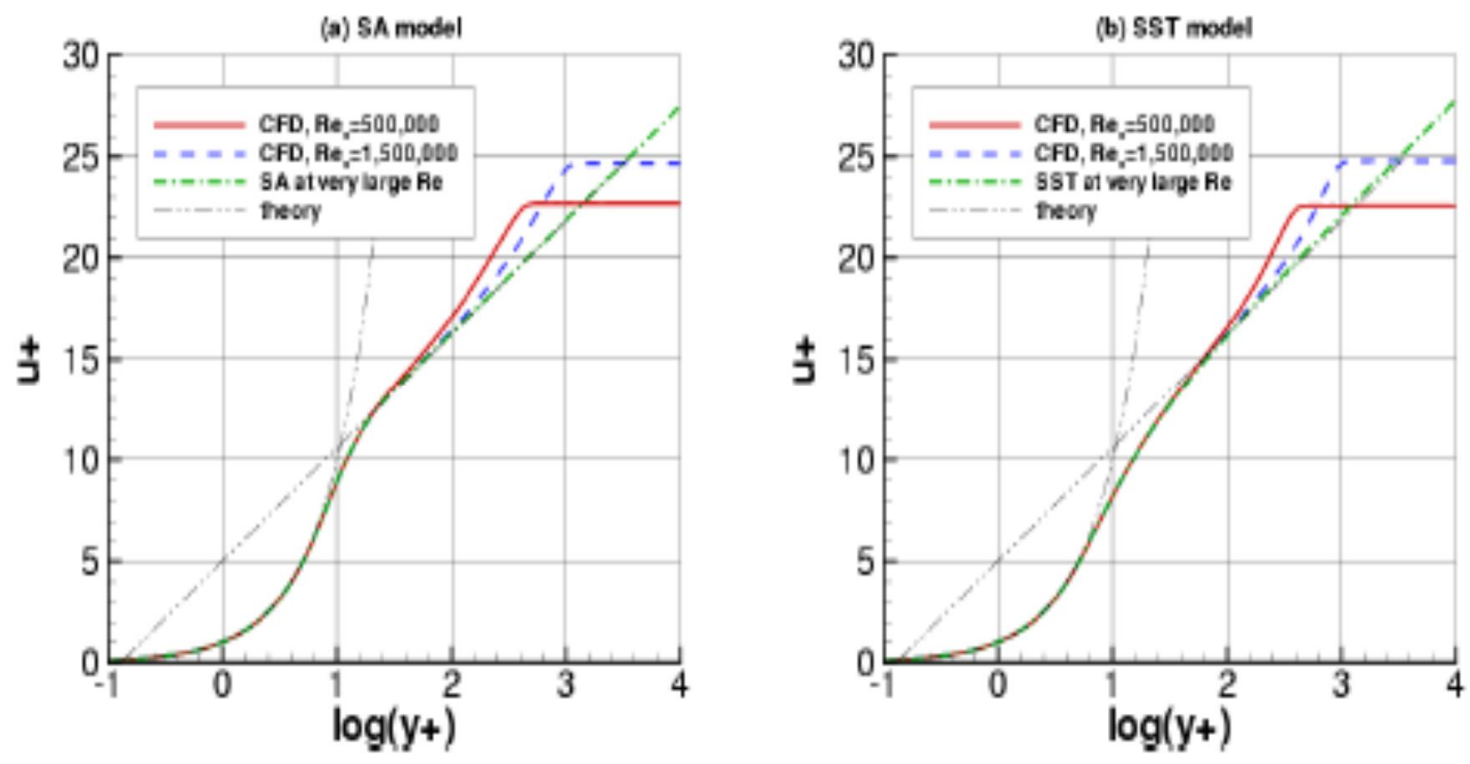

(b)

Fig. 5: (a) Typical y+ values in the turbulent boundary layer from [24]; (b) Velocity profiles in wall units for subsonic flow over flat plate, $\mathrm{M}=0.2, \operatorname{ReL}=1 \times 106$, medium grid [23, 24]. These data are used as reference in assessing the validity of the present computational results using COMSOL ${ }^{\circledR}$.

$$
y^{+}=\frac{u_{\tau} y}{v}=\frac{\left(\frac{\tau_{w}}{\rho}\right)^{\frac{1}{2}} y}{v}
$$


Very close to the wall, viscous damping reduces the tangential velocity fluctuations, while kinematic blocking reduces the normal fluctuations. Towards the outer part of the nearwall region, however, the turbulence is rapidly augmented by the production of turbulent kinetic energy due to the large gradients in mean velocity. Accurate presentation of the flow in the near-wall region determines successful prediction of wall-bounded turbulent flows.

However, the $\mathrm{COMSOL}^{\circledR}$ CFD software does not have the provision of utilizing Menter's Shear Stress Transport $k-\omega$ turbulent model, which was intended for appropriate selection of the computational grid near the airfoil surface as well as validity check on the computational procedure for further use in the parametric study. Therefore, resort is made to an earlier Wilcox's $k-\omega$ turbulent model [24].

Applying the present CFD code for the case of flat plate in similar conditions for $\mathrm{Re}=$ $1 \times 10^{6}$ like those considered by Rumsey and Spalart [25], the velocity profile is given in Fig. 6(a) (also placed as an insert in Fig. 6(b)). Comparing these results to Fig.5, taken from [23, 26], one may conclude that the present procedure to predict velocity profile near the wall can be justified for the present Reynolds number value and if there are no separation, but need further refinement for higher Reynolds numbers where boundary layer separation may ensue.

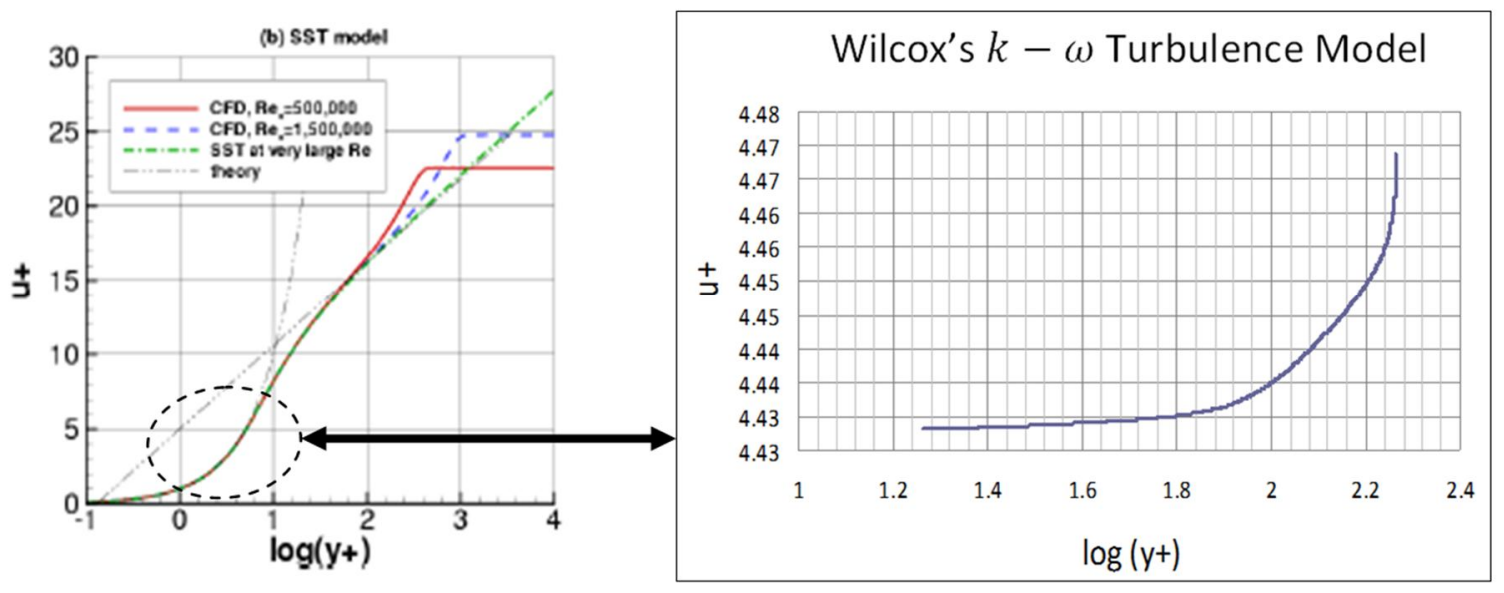

(a)

(b)

Fig. 6: Velocity profiles in wall units for subsonic flow over flat plate, $\operatorname{Re}=1 \times 10^{6}$, medium grid (as a basis for justification of the present numerical simulation) [23, 26]. The inset is the computational verification result using COMSOL and Wilcox k- $\omega$ Turbulence Model.

\subsection{BaselineValidation}

Another study is carried out to compare the present computational results for the pressure distribution on NACA2412 airfoil with results obtained using Airfoil 2.1® code, which only uses Navier-Stokes equation for laminar boundary layer, as exhibited in Fig. 7. Taking into account that the present study is carried out within limited range of Reynolds number and flow without separation, it may be surmised that for the parametric study of Coanda-jet effects on the L/D performance of a two-dimensional airfoil, the utilization of the present procedure and COMSOL ${ }^{\circledR}$ CFD code can carried out within such limitation. 


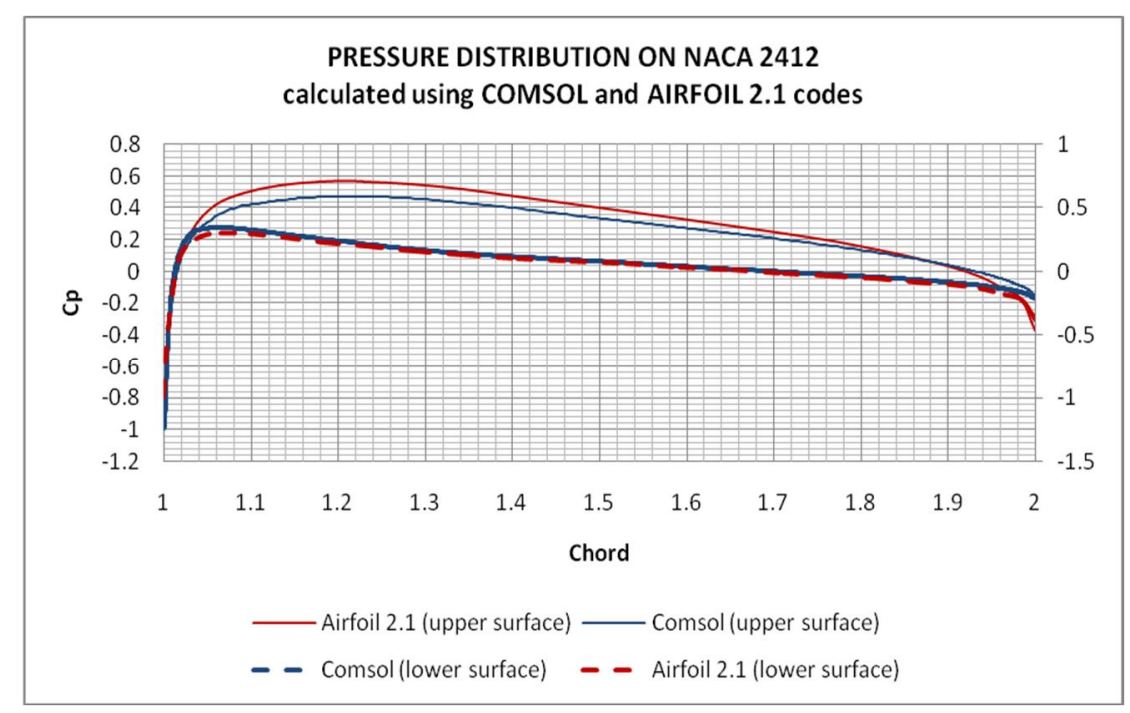

Fig. 7: Comparison of pressure distribution curve on NACA2412 airfoil at $\operatorname{Re}=1 \times 10^{6}$ as compared to that obtained by using Aerofoil 2.1@ CFD software (demo-version).

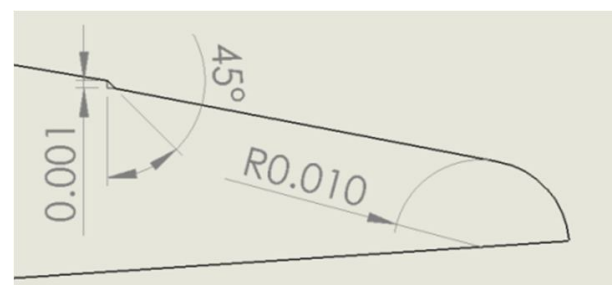

Fig. 8: Construction of rounded trailing edge; note the flat surface at the lower side of the airfoil in the vicinity of the trailing edge (Dimension in meter).

\subsection{BoundaryConditions}

Nonreflecting boundary conditions are applied at the outer boundaries of the computation domain. The jet is set to be tangential to the blade surface at the Coanda-jet nozzle location. The jet velocity profile is specified to be uniform at the jet exit.On the airfoil surface, except at the jet exit, no-slip boundary conditions are applied. To gain benefits, the jet velocity should be designed to be larger than the potential flow velocity at the vicinity of the outer edge of the boundary layer. In addition, the thickness of the Coanda jet is designed to be less than the local boundary layer thickness.

\subsection{ComputationalStudies on Airfoil for Wind-Turbine Application}

A thorough review has been made in the computational procedure adopted by the CFD code in the present numerical experiments, in the sense that first principles of mass, momentum and energy conservation have been followed closely, as well as that appropriate boundary conditions have been applied for the particular problem considered. Validation of the outcome of these procedures are exemplified by critical assessment of baseline cases, such as that illustrated by Fig. 2. 
In order to assess by numerical means the lift enhancing effect of Coanda-jet, baseline study will first be carried out on NACA2412, which is considered to be typical for wind turbine application. The free-stream velocity and the chord-length of the airfoil chosen for the study are taken to be commensurate with typical wind-turbine situation for Reynolds number of $10^{6}$ (one million). A Coanda-jet configuration will then be developed, by modifying its trailing edge to be rounded, adding a back step in the vicinity of the rounded trailing edge and assuring continuous and smooth upper surface curve, and then choose the Coanda-jet (hence back-step) thickness and its velocity. In the parametric study carried out, the jet velocity is chosen to be the same or larger than the local velocity at the outer edge of the boundary layer. From these parametric studies, some impression on the best configuration could be obtained.

Based on the information gained from there, similar parametric study is then carried out for S809 airfoil, which is a typical airfoil specifically designed and utilized for HAWT's applications [20] and investigated in [16-19].

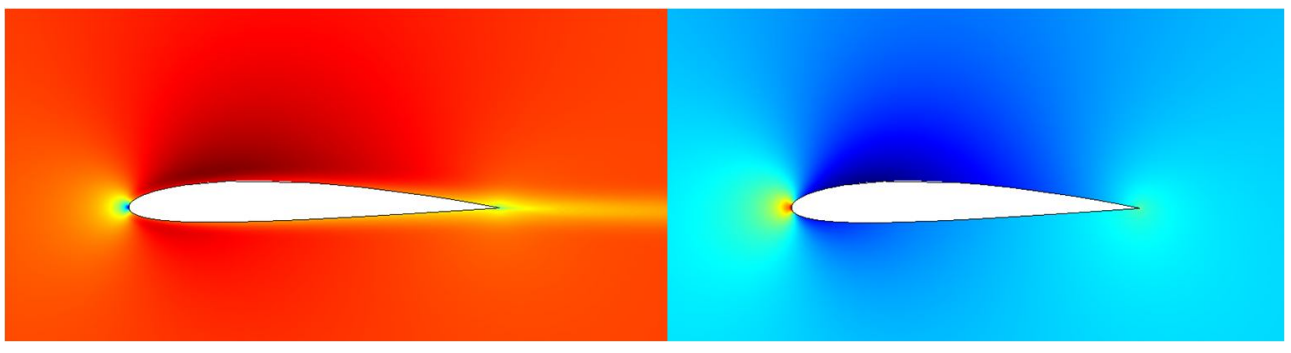

(a)

(b)

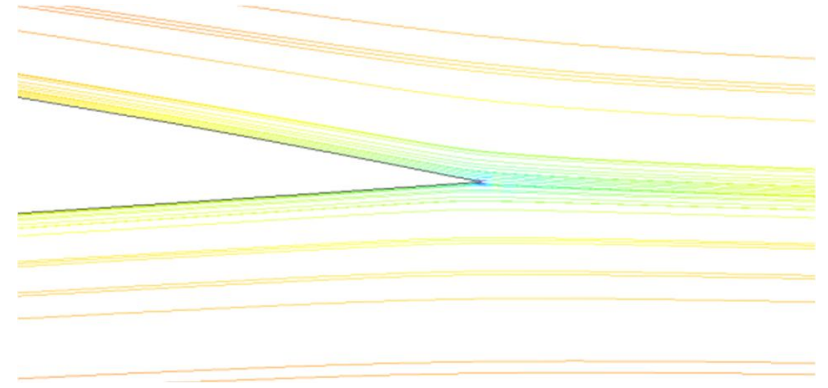

(c)

Fig. 9: (a) Velocity field, NACA 2412; (b) Pressure distribution, NACA 2412; (c) Velocity Streamlines near the trailing-edge of NACA 2412 airfoil.

\section{RESULTSAND DISCUSSION}

\subsection{DesignStudy Results for Baseline Airfoil}

Initial assessment on the effect of adding a Coanda jet on an airfoil in enhancing the lift using NACA2412 should be accompanied by introducing rounded trailing edge.Figure 10 describes the approach taken in this direction to arrive at rounded trailing edge configuration, taking into account that for best effect of Coanda-jet configuration the lower surface near the trailing edge should be flat, as suggested by Tongchitpakdee[17,18]. Further assessment follows. 


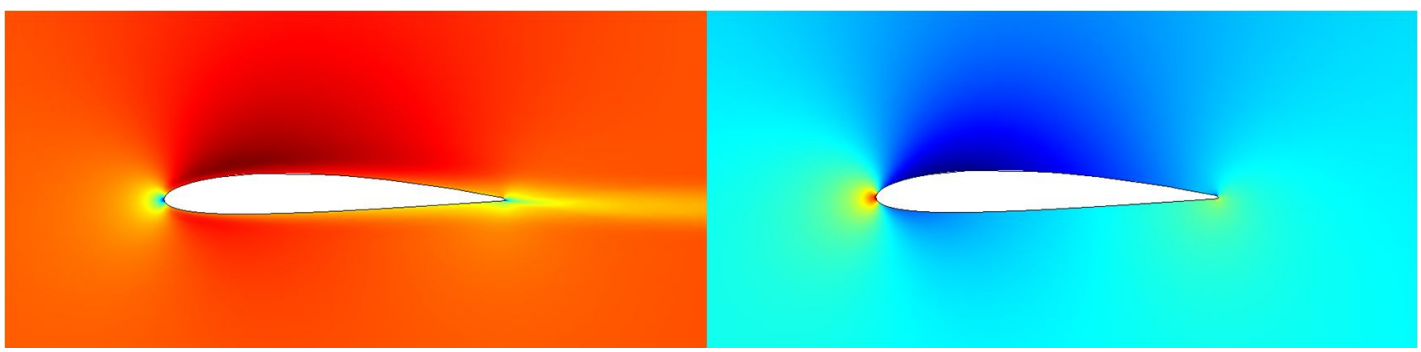

(a)(b)

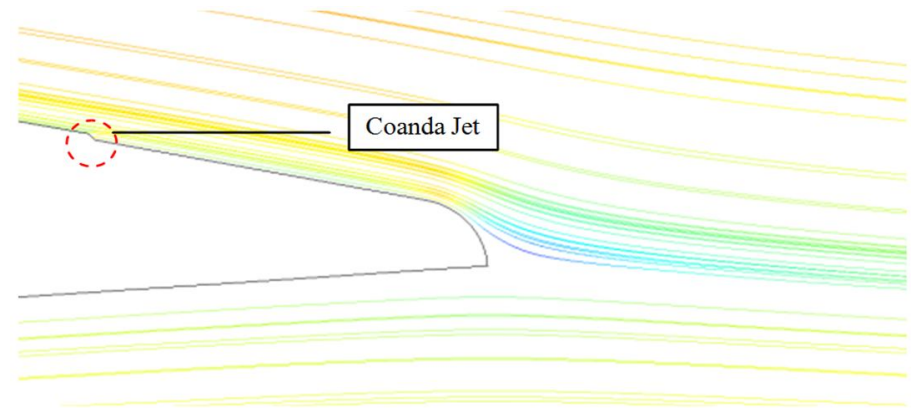

(c)

Fig. 10: (a) Velocity Profile, NACA 2412 with Coanda-jet; (b) Pressure distribution, NACA 2412 with Coanda-jet; (c) Velocity Streamlines near NACA 2412 TE, with Coanda-jet.

\subsection{ComputationalResults for NACA2412 Airfoil}

\subsubsection{Computational Results for Clean (baseline) NACA2412 Airfoil}

In the analysis and assessment of airfoil in propeller and wind-turbine configurations, a comprehensive review will be carried out to assess its performance in a series of configurations, for axial thrust (lift), mass flow rate or torque producing mode; the corresponding gain or changes in lift, drag and moment will be assessed. Figures 11a-12b typify the fluid property fields for flow around NACA2412 airfoil in clean (baseline configuration), where $\mathrm{V}_{\infty}=10 \mathrm{~m} / \mathrm{sec}$, chord length $\mathrm{c}=1 \mathrm{~m}$ and Reynolds number of $10^{6}{ }^{2}$ Notice the detail of the flow field exhibited there.

\footnotetext{
${ }^{2}$ The Reynolds number of $10^{6}$ was chosen since we are looking at a medium size wind-turbine, for which such value would be typical. In the CFD work using COMSOL, for the NACA2412 airfoil, Reynolds number of $10^{6}$ was obtained by having assumed the approximate density and viscosity values of air to be $\rho=1 \mathrm{~kg} / \mathrm{m}^{3}$ and $\mu=10^{-5} \mathrm{~kg} / \mathrm{m}$-sec, while for $\mathrm{S} 809$ actual typical values taken were $\rho=1.225 \mathrm{~kg} / \mathrm{m} 3$ and $\mu=1.789 \times 10^{-5} . \mathrm{kg} / \mathrm{m}-\mathrm{sec}$. Correspondingly, the appropriate velocity for the free-stream is $14.6 \mathrm{~m} / \mathrm{sec}$.
} 


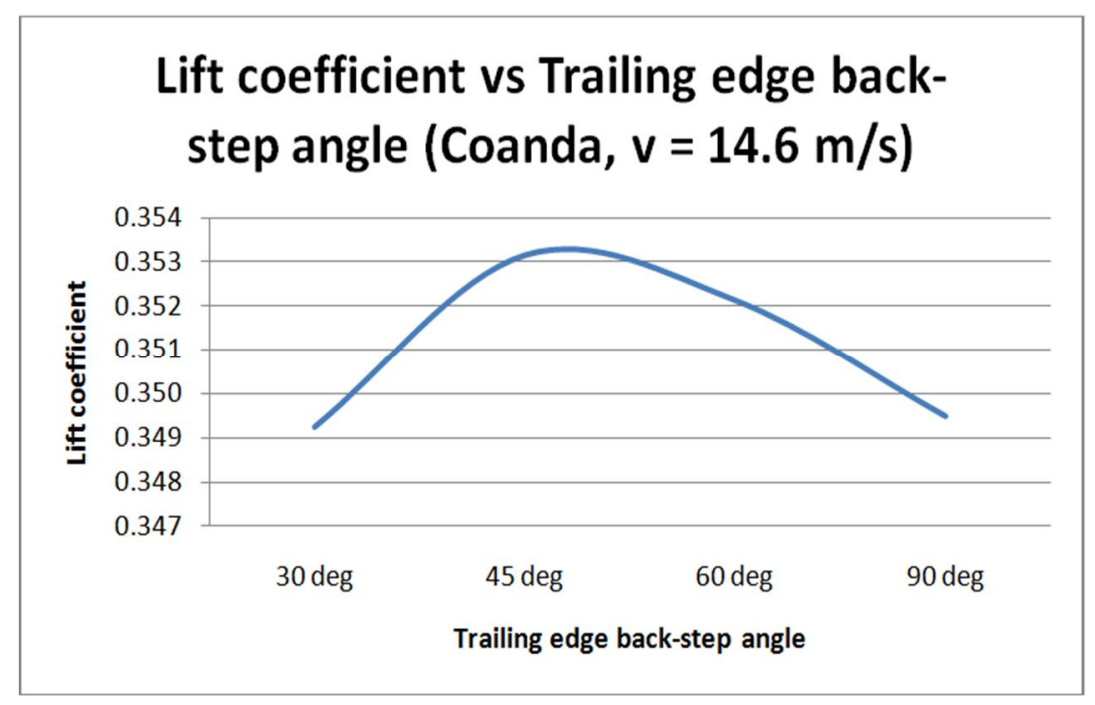

(a)

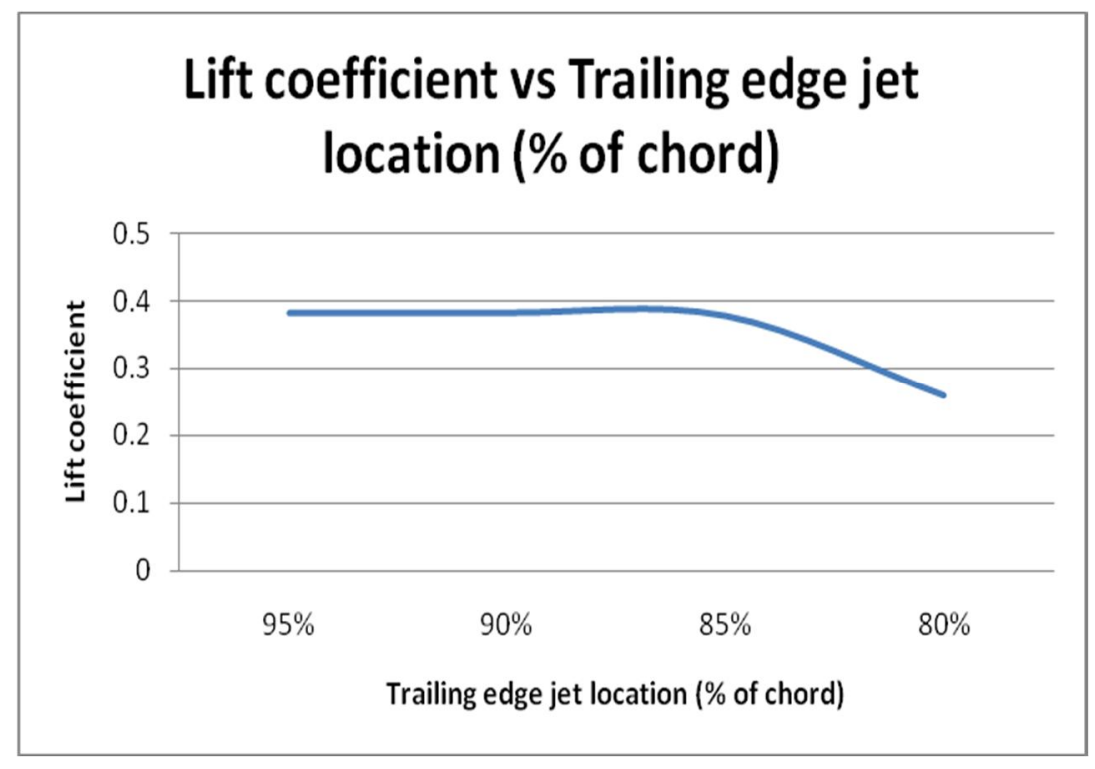

(b)

Fig. 11: (a) Influence of Coanda-jet location (NACA 2412); (b) Influence of back-step angle (NACA 2412) 


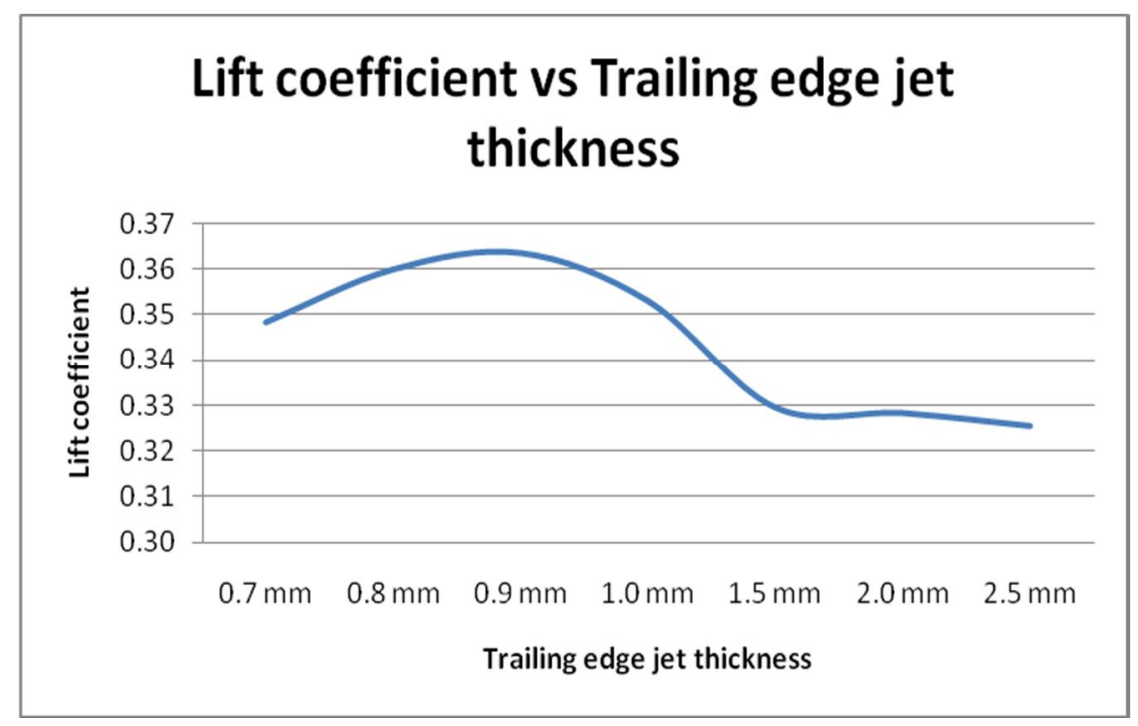

(a)

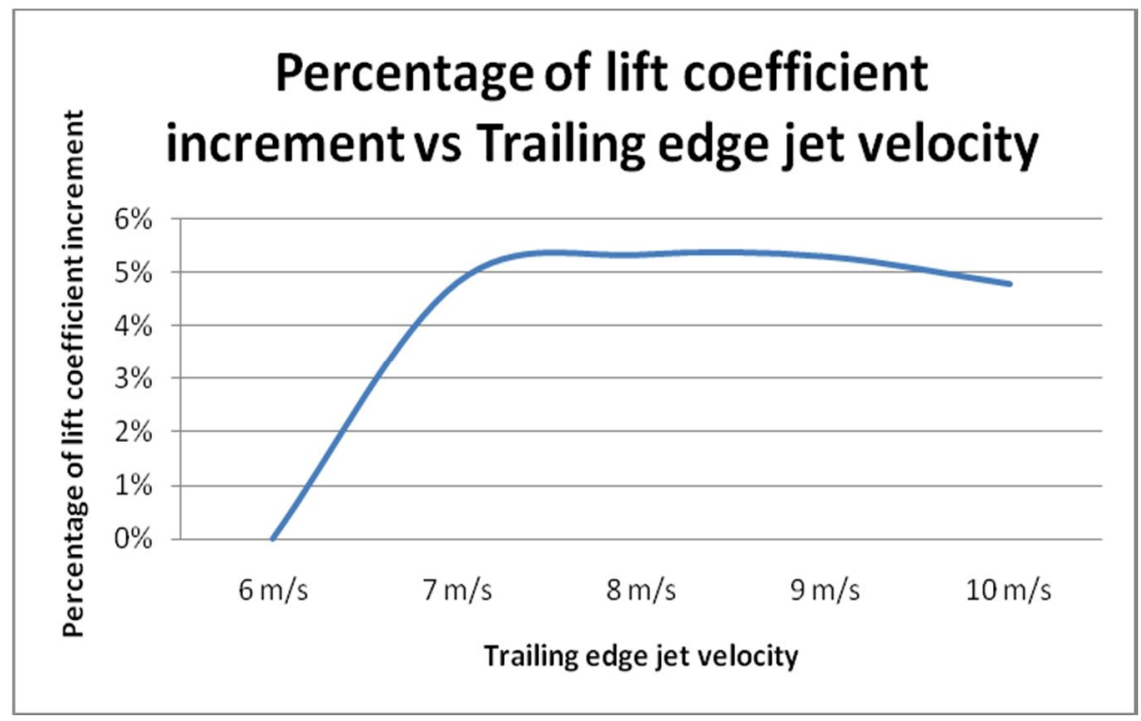

(b)

Fig. 12: (a) Influence of jet thickness (NACA 2412);

(b) Influence of Coanda jet influx velocity (NACA 2412)

\subsubsection{ComputationalResults for Coanda-jet Configured NACA2412 Airfoil}

Figures 10a-12b typify the fluid property fields for flow around Coanda-jet configured NACA2412 airfoil, where $\mathrm{V}_{\infty}=10 \mathrm{~m} / \mathrm{sec}$, chord-length $\mathrm{c}=1 \mathrm{~m}$ and Reynolds number of $10^{6}$. The Trailing Edge rounding has been carried out through parametric study by varying its radius, following the procedure illustrated in Fig. 8, and a reasonable (optimum in first inspection sense) round-off radius $\mathrm{R}_{\mathrm{TE}}=10 \mathrm{~mm}$ is set. The effect of varying the Coanda-jet nozzle location, back-step angle (with respect to local normal), Coanda-jet thickness and velocity are exhibited in Figures 11a-12b. The ensuing Lift or L/D ratio could be set as the deciding variable for the choice of Coanda-jet configuration. In summary, the introduction of Coanda- 
jet has resulted in increased (favorable) Lift or L/D ratio, which can be tailored following the design objectives set.

\subsection{ComputationalResults for S809 Airfoil}

Next, we would like to investigate the influence of specifically designed airfoil geometry for wind turbine application, and for this purpose a typical S809, in clean and Coanda-jet equipped configurations. S809 airfoil represents one of a new series of airfoils which are specifically designed for HAWT applications [17]. For the present study, the free-stream velocity $\mathrm{V}_{\infty}=14.6 \mathrm{~m} / \mathrm{sec}$ was assumed, while the chord-length $\mathrm{c}=1 \mathrm{~m}$ and Reynolds number of $10^{6}$. The baseline for assessing the advantage of Coanda-jet is the clean airfoil. For S809 the L/D for the clean configuration at zero angle of attack was found to be 6.78.

In HAWT optimum design, the wind-turbine blade may comprise different airfoil profiles at different radial sections. CFD computation for Coanda-jet tailored S809 airfoil without Coanda-jet is first carried out, and then followed by its corresponding Coanda-jet configuration.

\subsubsection{ComputationalResults for Coanda-jet Configured S809 Airfoil}

Figures 13(a)-15(b) typify the fluid property fields for flow around Coanda-jet configured S809 airfoil. Appropriate (optimum by inspection) Trailing Edge rounding radius has also determined through parametric study for flow around S809 airfoil with back-step without Coanda-jet. Starting from the clean wing, the trailing-edge rounding and the positioning of the back-step is determined by carrying out parametric study by varying the Trailing-edge rounding off radius RTE.

By varying this radius from 20 to $50 \mathrm{~mm}$, the L/D value varies as shown in Fig. 13(a). The lower curve exhibits the computational result without Coanda-jet. The determination of the optimum round-off radius at Trailing-Edge (lower-blue curve) is based on L/D as a criterion. Based on this result, a radius of RTE $=40 \mathrm{~mm}$ was selected, since larger radii results in lower $\mathrm{L} / \mathrm{D}$ values. When the Coanda-jet is activated (upper-red curve), significant enhanced L/D performance is obtained with a shift in the optimum position. This result (and the following one) are commensurate with the rounding-off procedure such that a smooth upper surface always prevails (if the back-step height degenerates to zero), as depicted in Figure 13(b). The placement of the back-step for Coanda-jet blowing follows the procedure schematically depicted by Fig. 8. Further movement upstream gives less L/D, and it is not possible to move it further downstream.

Figure 14(a) shows the effect of Coanda-jet nozzle location, i.e. the back-step, to L/D performance and indicated that the best back-step position is directly at the end of the quarter circle describing the rounding-off trailing-radius and tangent to it. Figure 14(b) shows the influence of the back-step angle to L/D performance of the Coanda-jet configured airfoil. The computation was carried out for back-step location at $85.9 \%$ (tangential), 85\%, 75\% and 70\% of chordline measured from LE. The optimum back-step angle with respect to the local vertical was found to be within 30 to 45 degree. Further computation was then carried out using optimum configuration thus obtained. Figures 15(a) and (b) exhibit parametric study results for Coanda-jet thickness and velocity, respectively, which can be used to determine desirable design values from L/D ratio considerations. 


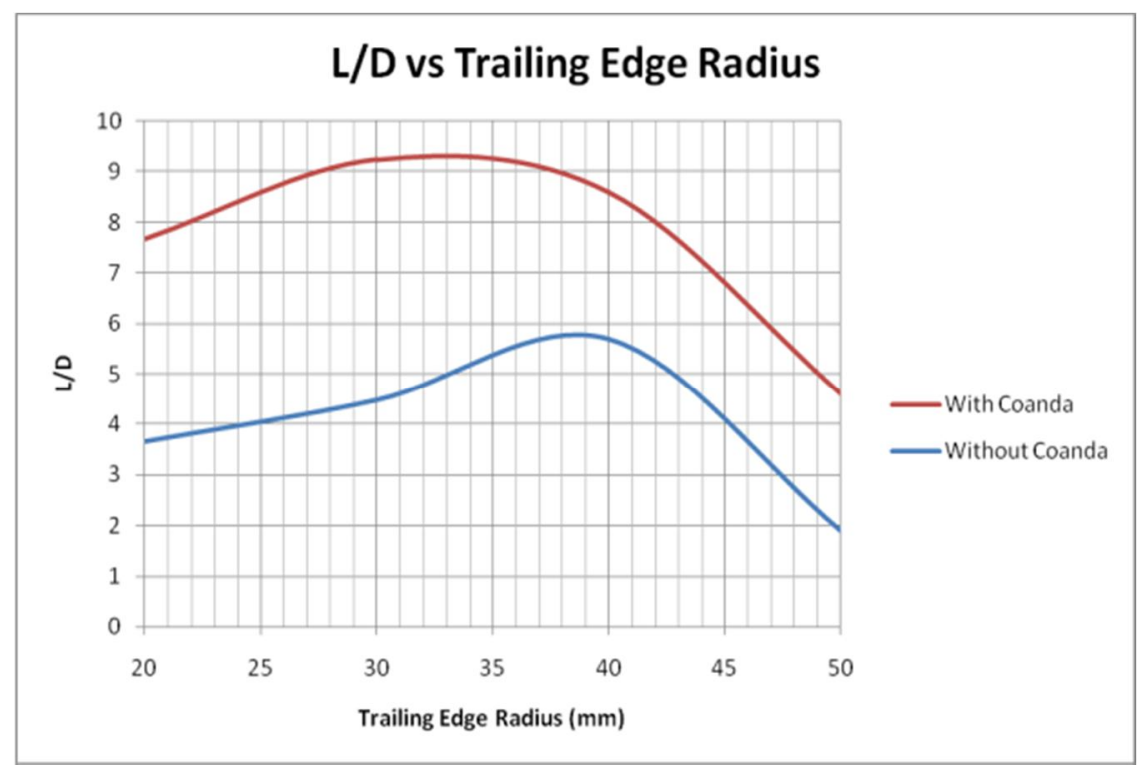

(a)

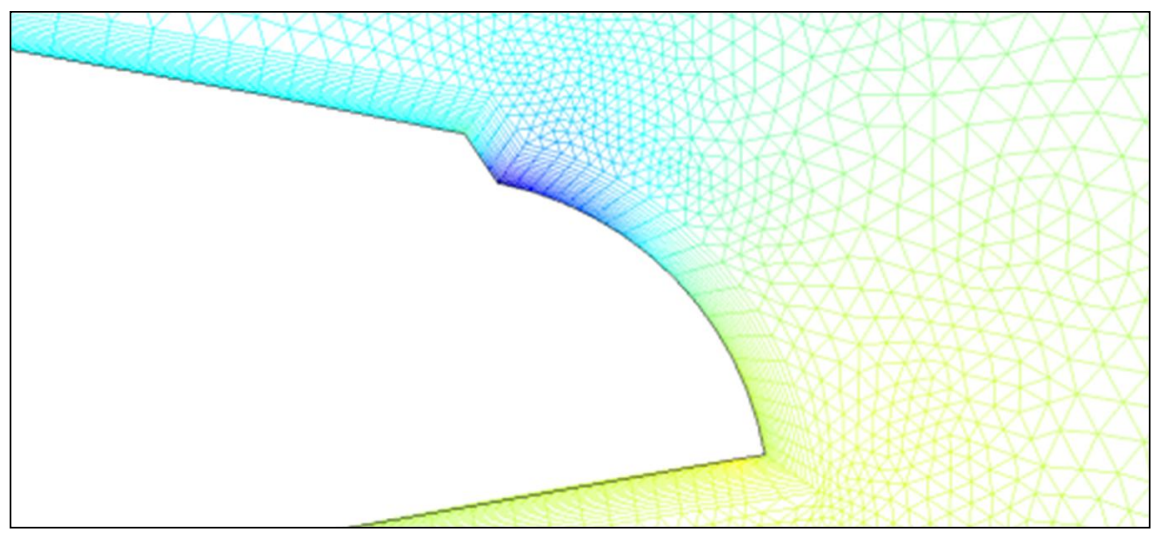

(b)

Fig. 13: (a) Parametric study to determine the optimum round-off radius at Trailing-Edge (lower-blue curve) using L/D as a criterion (S809); (b) Illustration of the location of the back-step for Coanda-jet for optimum results (S809)

\subsection{Analysis and Discussion}

\subsubsection{CFD Results for Coanda-jet Configured NACA2412 and S809 Airfoils}

From the CFD numerical computations of the flow-field around two-dimensional airfoils NACA2412 and S809, the introduction of Coanda-jet as configured in the present work results in enhanced $\mathrm{L} / \mathrm{D}$, which depend on the jet velocity. In the present work, parametric study carried out started with uniform jet velocity with the same magnitude as the free stream velocity, and varied it until about twice as much. Within this range, taking note of the particular rounding-off radius and back-step geometry, S809 results show monotonous increase of L/D, as shown in Fig. 15f, while for NACA2412, the introduction of Coanda-jet may not give the desired effect for the jet velocity above a certain value (Fig. 12b). 


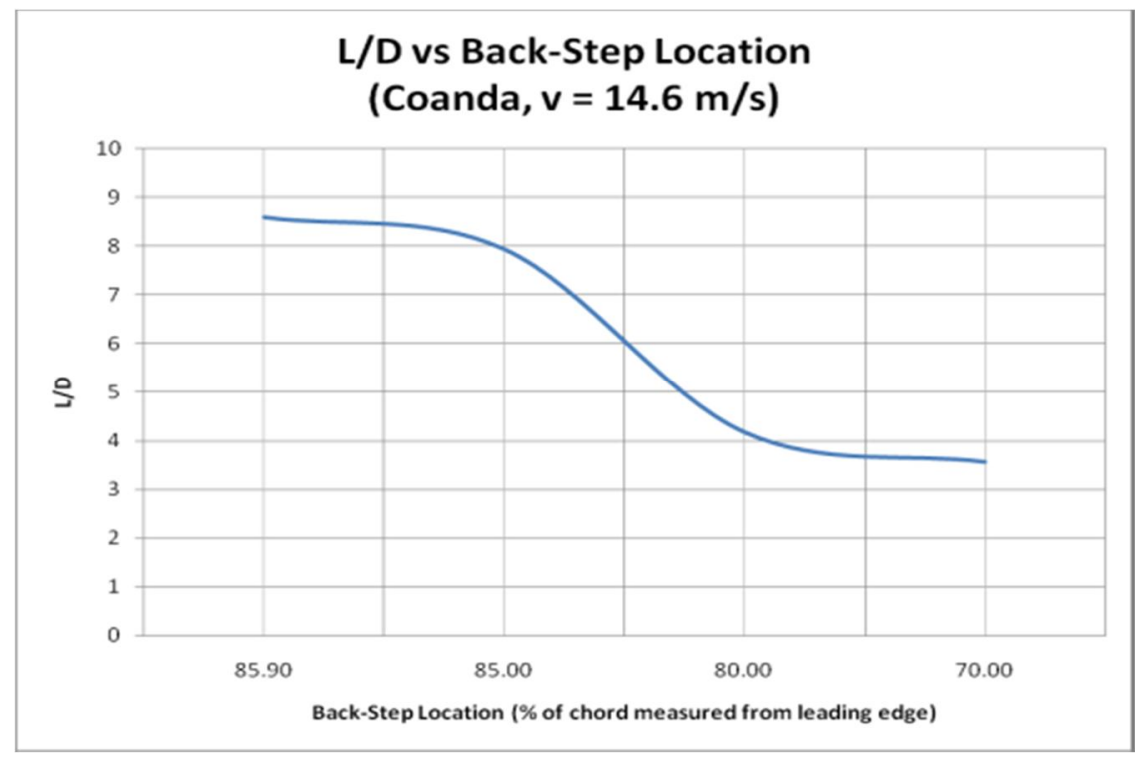

(a)

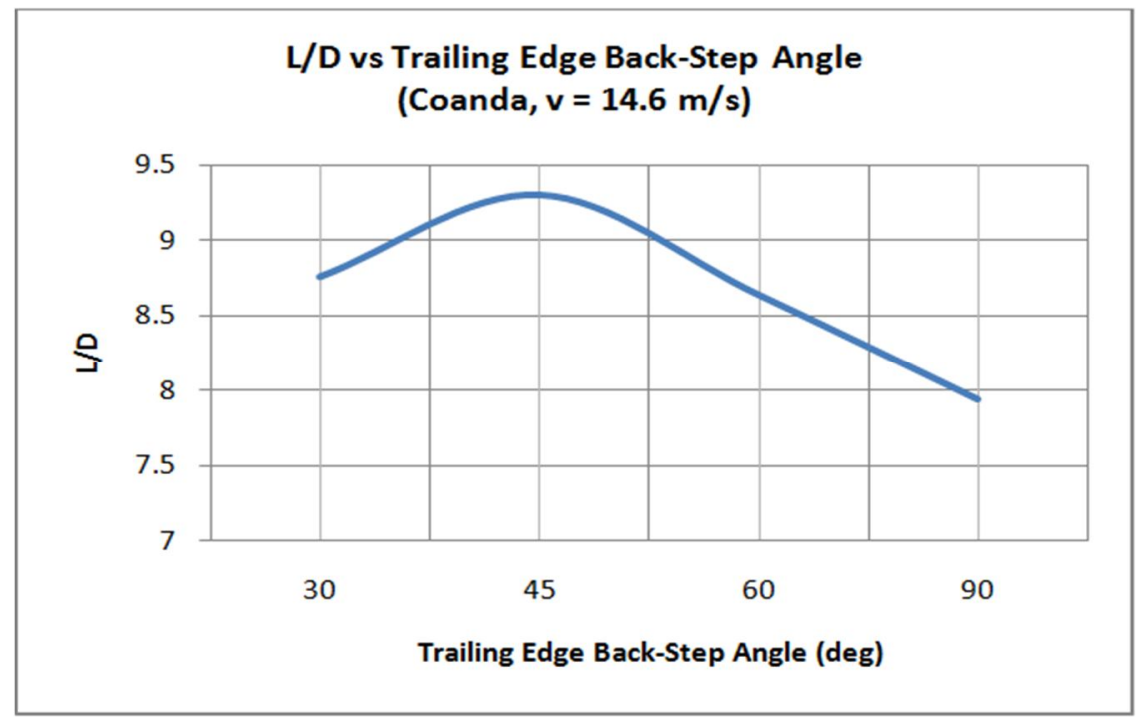

(b)

Fig. 14: (a) Influence of back-step location (S809); (b) Influence of back-step angle; the backstep angle is measured from the local vertical to the chord at the backstep position (S809). 


\subsubsection{Effect of Coanda-jet ${ }^{3}$}

It should be noted that for the purposes of the present work, a uniform jet velocity profile has been adopted, which could be readily modified for more realistic situation. Numerical results indicate that there exists an optimum Coanda-jet configuration, which has been the subject of parametric study as exhibited in Fig.12 (NACA2412) and Fig. 15 (S809) in section 5.3.

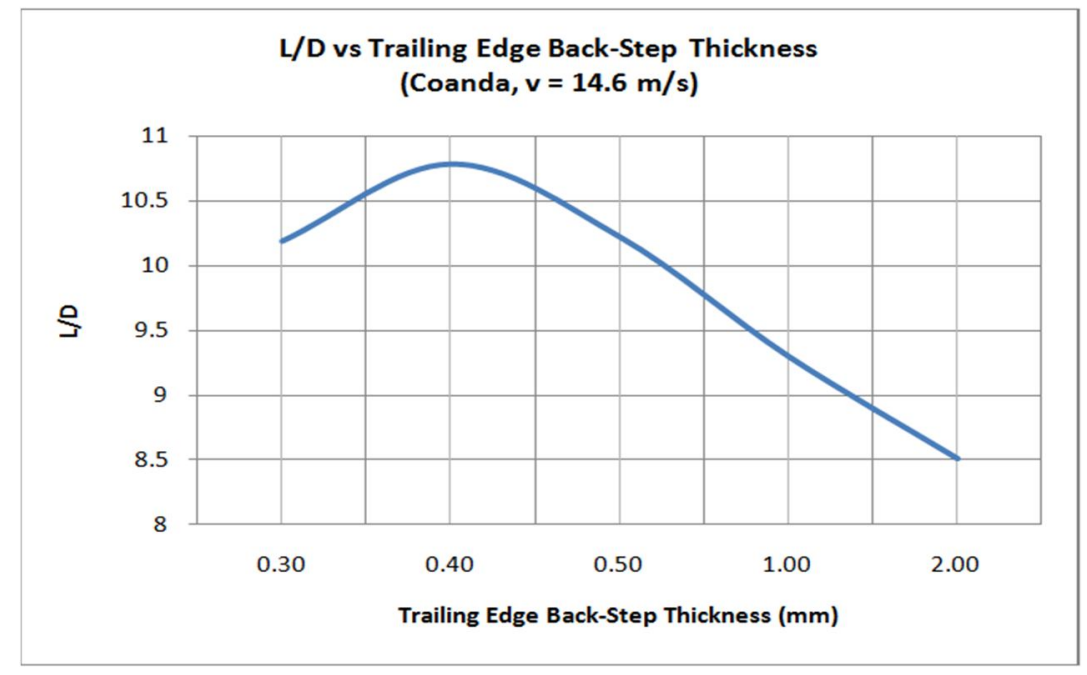

(a)

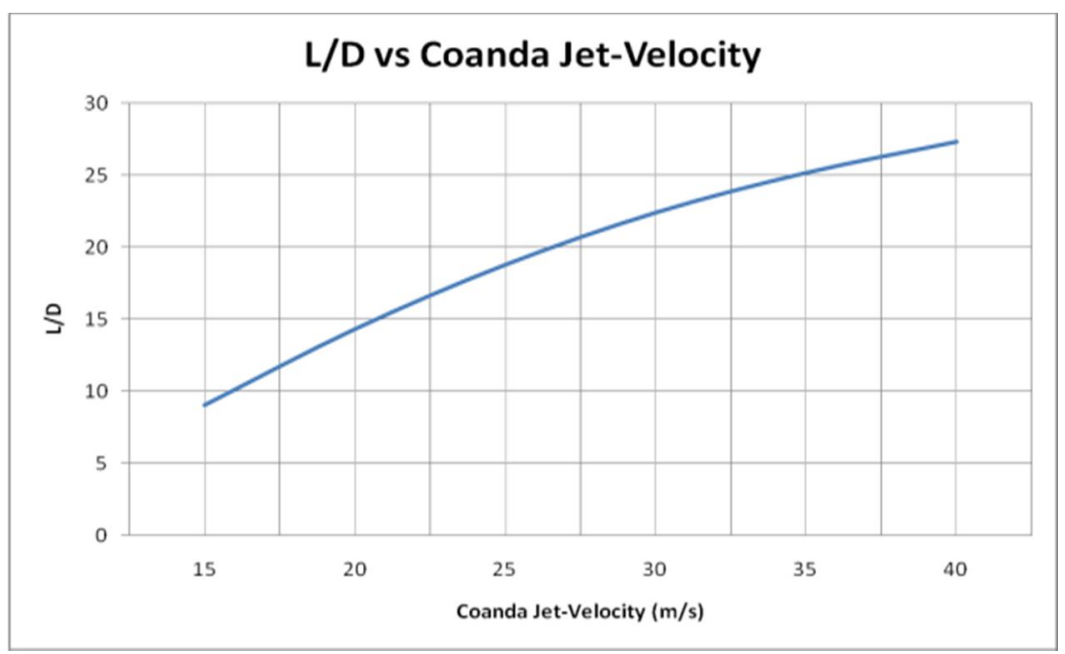

(b)

Fig. 15: (a) Influence of Coanda-jet thickness (S809); (b) Influence of Coanda-jet velocity (S809).

\footnotetext{
${ }^{3}$ The present work is devoted only to two-dimensional airfoil performance studies through CFD numerical experiments, and has been motivated by works related to Coanda-jet circulation control for improved performance of wind-turbines (in particular but not exclusively HAWT). Some discussions on the comparison of the application of Coanda jet for airfoil in propeller configuration is elaborated in an earlier work [28].
} 
Following the investigation carried out in $[2,4]$, the Coanda-jet (jet slot) boundary condition is specified by the momentum coefficient of the jet, $C_{\mu}$, which for our twodimensional modeling an equivalent constant $C_{\mu}^{*}$ can be defined as:

$$
C_{\mu}^{*}=\frac{\dot{m} V_{\text {Coanda-jet }}}{\frac{1}{2} \rho V_{\infty}^{2} A_{\text {ref }}}=\frac{\rho V_{\text {Coanda-jet }}^{2} t_{\text {Coanda-jet }}}{\frac{1}{2} \rho V_{\infty}^{2} c_{\text {aiffoil }}} \text { (2) }
$$

assuming that the density of the Coanda-jet is the same as the density of the ambient air.

This expression shows that for a given constant $C_{\mu}^{*}$, changing the thickness of the Coanda-jet will affects $C_{\mu}^{*}$ favorably.

For the three-dimensional configuration, there is a physical relationship between the Wind-Turbine shaft torque (which is a direct measure of the shaft power extracted) with $C_{\mu}$, and in the actual three-dimensional case, the wind-turbine rotor yaw angle [17, 18]. Tongchitpakdee [18] indicated that for the baseline unblown case, which here corresponds to the clean airfoil configuration, the turbine shaft torque cannot exceed the value given by theoretical Betz limit of,

$$
P_{\text {Betz }}=\frac{8}{27} \rho A_{\text {wind-turbine-rotor }} V_{\infty}^{2}(3)
$$

where $V_{\infty}$ is the wind speed, but with the introduction of Coanda-jet, this limit can be exceeded.

In this conjunction, with the present numerical results gained thus far, it can be surmised that circulation control, which in this particular case obtained by utilizing Trailing-edge Coanda-jet, through the L/D increase and hence the increased value of $C_{\mu}^{*}$ given by Equation (2), increases the torque generated. However, the Betz limit as given by Equation (3), may not be exceeded, since the input energy for the Coanda-jet should also be considered.

To justify the results of the present study, and to give us a physical explanation of the effect of Coanda-jet, one may attempt to carry out simple calculation using first principle and Kutta-Joukowski law for potential flow. In this conjunction, the Lift of the Coanda-jet configured airfoil is equal to the lift of the clean one obtained using COMSOL ${ }^{\circledR}$ CFD code and lift contributed by the Coanda-jet, and is given by

$$
L_{\text {Coanda-configured-airfoil }}=L_{\text {clean-airfoil }}+\rho V_{\infty}\left(V_{\text {Coanda-jet }} h_{\text {Coanda-jet }}\right) \text { (4) }
$$

where $h_{\text {Coanda-jet }}$ is the moment arm of the Coanda-jet with respect to the airfoil aerodynamic center.

One then arrives at a very good conclusion on the contribution of the Coanda-jet to the lift (surprisingly, using COMSOL $®$ CFD results for the L values, the accuracy obtained by 
using equation (4) was in the order of $1.39 \%$ ). However, care should be exercised to insure valid modeling for comparison.

\section{CONCLUSION AND FURTHER WORK}

The CFD numerical experiments carried out in this work serves as a first step towards better understanding of the characteristics of Coanda-jet lift enhanced airfoil configuration and how it can be best utilized.

The studies carried out thus far have shown that the effect of Coanda-jet is effective in producing enhanced lift. By physical reasoning and extension to three-dimensional case, enhanced sectional lift could then contribute to increased torque for wind turbine application, and increased axial thrust for propeller application.

Noting how one can tailor the Coanda-jet configuration, which in the present case has been configured in the vicinity of the trailing edge, the present results are encouraging and can be further pursued for extended parametric studies and design oriented applications.

Rounding-off of the trailing edge for introducing Coanda-jet seems to be more convenient and effective in gaining L/D increase for Wind Turbine specifically designed airfoil, here exemplified by S809. Such result may be due to the relatively large trailing edge angle of the Wind Turbine Specifically designed airfoil, and may lead to better aerodynamic performance of such airfoil compared to the reference airfoil used as the baseline (see Fig. 13a).

The results thus far obtained are computed for two-dimensional airfoil configuration, and their effects in modifying aerodynamic performance in general agree with those obtained for three-dimensional results of Tongchitpakdee [17-18]. Hence, the two-dimensional numerical study can be used to extend further utilization of the CFD computational procedure to the three-dimensional Wind-Turbine blade studies and design optimization.

Numerical results presented have been confined to zero angle-of-attack case, which has been considered to be very strategic to exhibit the merit of Coanda-jet as lift enhancer. The numerical studies could be extended to increasing angle of attack to obtain more comprehensive information, for which the choice of turbulence model will be more crucial.

Based on the work and results thus far obtained, further computational studies and design optimization of Wind-Turbine blades, comparison of Coanda-jet lift enhanced airfoil with other related configurations such as Gurney flap or jet flap (which is beyond the scope of the present study) could be readily carried out.

Power requirements and power performance index (which should be carefully and objectively defined) should also be studied for practical design requirements.

\section{ACKNOWLEDGEMENT}

The work reported here has been carried out as part of the research carried out within the University Putra Malaysia Research University Grant Scheme (RUGS) No. 05-02-10-0928RU initiated in April 2010. The authors would like to thank Dr.Abdul Aziz of UPM for stimulating discussions, in particular for turbulent modeling, Dr. Faizal Mustapha for facilitating the research and i-Math Co. for making available COMSOL software for our trial 
runs. The corresponding author would like to thank University Putra Malaysia (UPM) and Universitas Al-Azhar Indonesia for the opportunity to carry out this research.

\section{REFERENCES}

[1] Lan, C. Edward and Campbell,James F. , "Theoretical Aerodynamics of Upper-Surface blowing Jet-Wing Interaction”, NASA TN D-7936, November 1975.

[2] Harris, Michael J., "Investigation Of The Circulation Control Wing/ Upper Surface Blowing High-Lift System On A Low Aspect Ratio Semispan Model", Report DTNSRDC/ASED-81/10, David Taylor Naval Ship Rand Center, Aviation and Surface Effects Department, Bethesda, Maryland, May 1981.

[3] Englar, R. J., Smith, M. J., Kelley, S. M., and Rover, R. C. III., "Application of Circulation Control to Advanced Subsonic Transport Aircraft, Part I: Airfoil Development", Journal of Aircraft, Vol. 31, No. 5, Sep. 1994, pp. 1160-1168.

[4] Englar, R. J., Smith, M. J., Kelley, S. M., and Rover, R. C. III., "Application of Circulation Control to Advanced Subsonic Transport Aircraft, Part II: Transport Application", Journal of Aircraft, Vol. 31, No. 5, Sep. 1994, pp. 1169-1177.

[5] Zhulev, Yu. G. and Inshakov, S. I., "On The Possibility Of Enhancing The Efficiency Of Tangential Blowing Of A Slit Jet From An Airfoil Surface", Fluid Dynamics, Vol. 31, No. 4, Plenum Publishing Corporation, 1996, Translated from Izvestiya Rossiiskoi Akademii Nauk, Mekhanika Zhidkosti Gaza, No. 4, pp. 182-186, July-August, 1996.

[6] Gad-el-Hak, Mohamed, "Modern Developments in Flow Control", in Applied Mechanics Reviews, Vol. 49, pp. 365-379, 1996.

[7] Englar, Robert J., "Advanced Aerodynamic Devices to Improve the Performance", Economics, Handling and Safety of Heavy Vehicles, SAE Technical Paper Series 2001-01-2072.

[8] Liu, Y., Sankar, L. N., Englar, R.J., and Ahuja, K., "Numerical Simulations of the Steady and Unsteady Aerodynamic Characteristics of a Circulation Control Wing", AIAA 2001-0704, 39th AIAA Aerospace Sciences Meeting, Reno, NV.

[9] Liu, Y., "Numerical Simulations of the Aerodynamic Characteristics of Circulation Control Wing Sections", PhD Dissertation, Georgia Institute of Technology, May 2003, www.ae.gatech.edu/ lsankar/NASA_CCWUTH.

[10] Wu, Jingshu, Sankar, Lakshmi and Kondor, Shayne, "Numerical Modelling of Coanda Jet Controlled Nacelle Configuration", Paper AIAA-2004-0228, 42 ${ }^{\text {nd }}$ AIAA Aerospace Science Meeting and Exhibit, Reno, Nevada, 5- 8 Jan 2004.

[11] Mamou, M. and Khalid, M., "Steady and unsteady flow simulation of a combined jet flap and Coanda jet effects on a 2D airfoil aerodynamic performance", Revue des Energies Renouvelables CER'07 Oujda (2007) 55 - 60.

[12] Shojaefard, M.H., Noorpoor, A.R., Avanesians, A. and Ghaffarpour, M., "Numerical Investigation of Flow Control by Suction and Injection on a Subsonic Airfoil", American Journal of Applied Sciences 2 (10): 1474- 1480, 2005.

[13] Sinha, SumonK., "Optimizing Wing Lift to Drag Ratio Enhancement with Flexible-Wall Turbulence Control", http://sinhatech.com/ AIAA-2007-101APA21-Draft.pdf.

[14] Radespiel, R., Pfingsten, K.-C. and Jensch, C., "Flow Analysis of Augmented High-Lift Systems", TU Braunschweig, Institut für Strömungsmechanik, Bienroder Weg 3, D-38108 Braunschweig, Germany, Hermann Schlichting - 100 Years Memorial Volume, NNFM 102, pp. 168-189, Springerlink.com, () Springer-Verlag Berlin Heidelberg 2009. 
[15] Day, Terry, "The Coanda Effect and Lift", Copyright 2008. terry@vortex-dynamics.com.au; http://www.newfluidtechnology.com.au/THE_COANDA_EFFECT_AND_LIFT.pdf.

[16] Xu, Guanpeng, and Sankar, L. N., "Computational Study of Horizontal Axis Wind Turbines", UASME Journal of Solar Energy Engineering, Vol. 122, No. 1, February 2000, pp. 35-39.

[17] Tongchitpakdee, Chanin, Benjanirat, Sarun and Sankar, Lakshmi N., "Numerical Studies of the Effects of Active and Passive Circulation Enhancement Concepts on Wind Turbine Performance", Journal of Solar Energy Engineering, Transactions of the ASME, Vol. 128, NOVEMBER 2006, pp. 432-444.

[18] Tongchitpakdee, Chanin, "Computational Studies of the Effects of Active and Passive Circulation Enhancement Concepts on Wind Turbine Performance", PhD Dissertation, Georgia Institute of Technology, August 2007.

[19] Xu, G., "Computational Studies of Horizontal Axis Wind Turbines", PhD Dissertation, School of Aerospace Engineering, Georgia Institute of Technology, Atlanta, GA, 2001.

[20] Tangler, J., et al., "SERI Advanced Wind Turbine Blades", International Solar Energy Society Conference, Denver, Colorado, 1991.

[21] Sommers D.M. and Tangler, J.L., "Wind-Tunnel Tests of Two Airfoils for Wind Turbines Operating at High Reynolds Numbers", NREL Report, June 2000.

[22] Anderson, John D., Jr., "Introduction to Flight", McGraw-Hill International Edition, Singapore, 2005.

[23] Menter, Florian R., "Advances in Turbulence Modelling of Unsteady Flows", ANSYS, Germany, (C) 2009 ANSYS, Inc, 2009; also Menter Shear Stress Transport Model, http://turbmodels.larc.nasa.gov/sst.html.

[24] Wilcox, D.C., "Turbulence Modeling for CFD”, DCW Industries Inc., 1998.

[25] Rumsey, Christopher L. and Spalart,Philippe R., "Turbulence Model Behavior in Low Reynolds Number Regions of Aerodynamic Flow Fields", 38th AIAA Fluid Dynamics Conference and Exhibit, Seattle, WA, June 23 - 26, 2008.

[26] Salim, Salim M. and Cheah, S.C., "Wall y+ Strategy for Dealing with Wall-bounded Turbulent Flows", Proceedings of the International Multi-Conference of Engineers and Computer Scientists 2009 Vol. II, IMECS 2009, Hong Kong, March 18 - 20, 2009.

[27] Benjanirat, Sarun, "Computational Studies of Horizontal Axis Wind Turbines in High Wind Speed Condition Using Advanced Turbulence Models", PhD Thesis, Georgia Institute of Technology, December 2006.

[28] Abdul Hamid, M.F., Djojodihardjo, H., Suzuki, S. and Mustapha, F., "Numerical Assessment of Coanda Effect as Airfoil Lift Enhancer in Wind-Turbine Configuration”, paper RCMEAE-131, Proceedings, Regional Conference on Mechanical and Aerospace Technology, Bali, February 9$10,2010$.

\section{NOMENCLATURE}

CFD Computational Fluid Dynamic

CCW Circulation Control Wing

HAWT Horizontal Axis Wind Turbine

M Mach number

L/D Lift over drag ratio 
$h_{\text {Coanda-jet }} \quad$ Moment arm of Coanda-jet with respect to airfoil aerodynamic center

TE Trailing Edge

STOL Short Takeoff Landing

$y$

$V_{\infty}$

Dimensionless wall distance for a wall-bounded flow

$\mathrm{R}_{\mathrm{TE}}$

Wind speed

$\mathrm{m} / \mathrm{sec}$

$\mathrm{C}$

Trailing edge radius

$\mathrm{mm}$

$\mathrm{L}$

Airfoil chord length

$\mathrm{m}$

Lift force

D Drag force

$\mathrm{N}$

$\mathrm{H} \quad$ Coanda jet thickness

RTE Trailing-edge rounding off radius

$\mathrm{mm}$

$u_{\tau} \quad$ Friction velocity

$\mathrm{m}$

$y \quad$ Distance to the nearest wall

$\mathrm{m} / \mathrm{sec}$

$v \quad$ Kinematic viscosity

$\mathrm{m}$

$\tau_{w}$

Wall shear stress

$\mathrm{m}^{2} / \mathrm{s}$

$\rho$

Density

$\mathrm{N} / \mathrm{m}^{2}$

$\mathrm{kg} / \mathrm{m}^{3}$ 